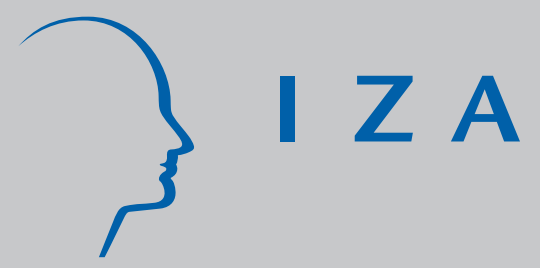

IZA DP No. 1247

A Simulation of an Income Contingent Tuition Scheme in a Transition Economy

Milan Vodopivec

August 2004 


\title{
A Simulation of an Income Contingent Tuition Scheme in a Transition Economy
}

\author{
Milan Vodopivec
}

World Bank and IZA Bonn

Discussion Paper No. 1247

August 2004

\author{
IZA \\ P.O. Box 7240 \\ 53072 Bonn \\ Germany \\ Phone: +49-228-3894-0 \\ Fax: +49-228-3894-180 \\ Email: iza@iza.org
}

Any opinions expressed here are those of the author(s) and not those of the institute. Research disseminated by IZA may include views on policy, but the institute itself takes no institutional policy positions.

The Institute for the Study of Labor (IZA) in Bonn is a local and virtual international research center and a place of communication between science, politics and business. IZA is an independent nonprofit company supported by Deutsche Post World Net. The center is associated with the University of Bonn and offers a stimulating research environment through its research networks, research support, and visitors and doctoral programs. IZA engages in (i) original and internationally competitive research in all fields of labor economics, (ii) development of policy concepts, and (iii) dissemination of research results and concepts to the interested public.

IZA Discussion Papers often represent preliminary work and are circulated to encourage discussion. Citation of such a paper should account for its provisional character. A revised version may be available directly from the author. 
IZA Discussion Paper No. 1247

August 2004

\section{ABSTRACT}

\section{A Simulation of an Income Contingent Tuition Scheme in a Transition Economy*}

The paper takes advantage of exceptionally rich longitudinal data on the universe of labor force participants in Slovenia and simulates the working of an income contingent loan scheme to partly recover tuition costs. The simulations show that under the base variant (where the target cost recovery rate is 20 percent and the contribution rate is 2 percent), 55 percent of individuals would have repaid their entire debt within 20 years; 19 percent of individuals still would not have repaid any of their debt after 20 years; and the "leakage" of the scheme due to uncollected debt would have been 13.5 percent of total lending. By piggybacking on existing administrative systems, implementation costs would be minimal, amounting to less than 0.5 percent of collected debt.

JEL Classification: I28, C15, J24

Keywords: income contingent loan, education, tuition, simulation

Milan Vodopivec

The World Bank

1818 H Street, NW

Washington, D.C. 20433

USA

Email: mvodopivec@worldbank.org

\footnotetext{
* The author wishes to thank the Statistical office of the Republic of Slovenia for providing data on students and the work history of the active population, the Slovenian Ministry of Education for data on tuition costs, Bruce Chapman and Peter Orazem for insightful comments, and Tomaž Rejec for outstanding research assistance. Special gratitude is owed to country experts who provided information about the capacity to implement income contingent loan schemes in transition countries: Marta Dekhtyarchuk, Raul Eamets, Mihails Hazans, Mariana Kotzeva, Leszek Kucharski, Anton Marcincin, Catalin Pauna, Tatyana Tchetvernina, Janos Toth and Jiri Vecernik.
} 


\section{INTRODUCTION: WHY ARE INCOME CONTINGENT LOAN SCHEMES PARTICULARLY ATTRACTIVE FOR TRANSITION COUNTRIES?}

Income contingent loans have increasingly been recognized as an appealing option for financing higher education. By shifting some of the financial burden to students such loans improve equity, as children from well-off families are typically disproportionally benefiting from government subsidies. Moreover and somewhat paradoxically, such loans can potentially improve access to education, both by ensuring the equality of opportunity and thus improving chances of talented but poor students, as well as by mobilizing resources and thus removing capacity constraints on enrollment in a form of quotas. And such loans can also improve efficiency of higher education. In comparison to an open enrolment regime, asking students to repay part of their study costs improves their incentives to shorten the study time. Income contingent loans would also attract students who, in the absence of such a scheme, would not enroll in higher education because of the high perceived risk of default on their student loan. Alternative solutions all have significant drawbacks commercial banks are not willing to lend because investment in education provides poor collateral, and the provision of government guarantee to such loans has created problems of its own which have led to low loan repayment rates. ${ }^{1}$

Income contingent loans have been introduced by several countries - among others, by Australia in 1989, New Zealand in 1991, and the UK in 1997 - and are being considered in several others. It seems that the arguments for the introduction of such schemes in European transition countries, particularly as a vehicle to introducing tuition in public higher education institutions, are especially strong:

- In the 1990s, there was a rapid expansion of student enrolment not accompanied by a commensurate increase of funding, so the need to mobilize additional resources is particularly pressing. ${ }^{2}$

- Several countries charge hefty tuition to part-time (evening) students and nothing to regular students, so the equity argument for the introduction of a unified tuition is stronger than elsewhere. ${ }^{3}$

\footnotetext{
${ }^{1}$ See Chapman (2003) for an excellent recent review article of income contingent loans in higher education.

${ }^{2}$ In Slovenia, for example, during the 1990s the number of students nearly tripled while the public spending on higher education as a share of GDP stayed constant. As a result, in 1995-2000 there was a 20 percent annual decrease in real public expenditures per student (Mramor, 2001).
} 
- Relying on income contingent loans is a politically more acceptable way of introducing tuition to public institutions which have traditionally offered free education to regular students.

- Introducing tuition would reduce the advantage of public institutions and thus stimulate competition via the entry of new providers - a particularly important way of improving quality of education in countries where supply considerations continue to determine the most important outcomes in higher education. ${ }^{4}$

- Strong increase of private benefits of education. All studies on transition economies find that the returns to education have increased, with the increases of highly educated groups being the largest (for a recent survey, see Rutkowski 2001).

- Last and certainly not least, there are strong administrative schemes in place which allow individuals to be tracked during their working lives and thus enable cheap and efficient debt collection - a critical issue for the viability of income contingent loan schemes.

Because income contingent loan schemes are a relatively new phenomenon, some of their important features have remained insufficiently researched. To shed additional light on the key features of such schemes, this paper exploits an exceptionally rich longitudinal data on the universe of labor force participants to simulate the working of an income contingent loan scheme to recover a part of tuition costs in one of the transition countries - Slovenia. It thus complements the simulation analysis reported by Barr and Crawford (1988) for the UK, and Chapman (1997) for Australia. Taking advantage of the exceptionally rich data sources, the paper also extends the simulation analysis in various dimensions. It has to be emphasized that although income contingent schemes have been in operation in some countries for a relatively long period (in Australia, for example, for 15 years), analyzing such

\footnotetext{
${ }^{3}$ The share of students paying tuition at public tertiary institutions ranges from 30 to 50 percent in Estonia, Latvia, Poland, Romania, Slovenia, and around 10 percent in Hungary, Russia and Ukraine. Tuition is charged to "evening" or part-time student, as well as regular students if the number of students exceeds predetermined quotas. The yearly tuition ranges from US\$400-500 in Romania to US\$2000-2500 in Slovenia (information obtained through personal communication with country experts).

${ }^{4}$ On the effects of entry of private providers on quality and accessibility of higher education in transition countries, see Kraft and Vodopivec (2003).
} 
schemes by its very nature requires a much longer time horizon - the entire work-life cycle of an individual - if they are to be fully understood.

The paper focuses on the financial performance of an income contingent loan scheme (financial leakages and the speed of cost recovery), and also explores some of its equity implications. It seeks to answer the following questions: What is the time path of the revenues generated by the scheme following its introduction? What are the financial leakages of the scheme? For example, what are the losses due to nonparticipation in the workforce, particularly of women discontinuing their labor market participation? How many of individuals who incur debt never repay any of it? Moreover, what are the combined financial losses from non-participation and the fact that the earnings of many individuals fall short, at least temporarily, of the incomerepayment threshold? What proportion of individuals repay their debt by the end of their working life? What is the financial performance of various groups, for example, graduates of certain study fields, and dropouts? The simulations also allow one to trace the earnings level of an average person repaying the loan, and to analyze the sensitivity of the scheme to changes in its parameters.

The main findings of the study are as follows: introducing income contingent loan scheme to partly recover tuition costs would substantially increase the resources of Slovenian higher education while only marginally decreasing the current earnings of those repaying the tuition. Assuming a 20 percent target recovery rate for education costs, a 2 percent income contribution rate and mandatory payments only for those with above-average earnings, the simulation results show that:

- 20 years after its introduction, the scheme would cover 14 percent of higher education costs, and 30 years after its introduction, 16 percent (under the alternative assumption of a 50 percent target cost recovery rate, the coverage would increase to 22 and 34 percent after 20 and 30 years, respectively);

- 55 percent of indebted individuals would have repaid their entire debt 20 years after beginning their studies, and 73 percent, after 30 years;

- individuals repaying income contingent loans would belong to a high earnings group - their mean earnings would be 54 percent above the national average. 
Because the implementation of the proposed scheme could rest on personal-income tax and other existing information systems, its recurrent costs would be minimal, amounting to less than 0.5 percent of collected debt.

The paper is organized as follows. Section 2 describes a methodology and data sources. Section 3 presents simulation results, both of the base variant as well as sensitivity analysis showing deviations from the base variant under different parameter options. Section 4 concludes.

\section{METHODOLOGY AND DATA SOURCES}

To analyze the functioning of an income contingent loan scheme, the paper simulates such a scheme for one transition economy: Slovenia. This section explains the method of simulation and describes data sources. As explained below, thanks to exceptionally rich administrative data bases covering all Slovenian labor force participants over a long period, the simulation rests on rather simple methodology, but one which offers rich possibilities for analyzing the features and desirable parameters of the income contingent loan scheme. Since it is one of the crucial steps in the simulation, we also explain in detail how we generated the complete, lifelong work histories of the simulation cohort.

\subsection{Methodology}

The simulations are based on the following methodology. For every student of a chosen cohort, we calculate how much debt is incurred during his or her study period, and examine how this debt is repaid during the working life of the individual. We assume that the tuition is charged for each academic year of enrollment, and that the debt is subject to a certain interest rate. The level of annual repayment is determined by the prescribed annual contribution rate applied to an individual's yearly earnings, and the repayment takes effect only in years when the person's earnings exceed the threshold determined by the scheme. The repayments stop when the debt is repaid in full; any unpaid debt at the time of retirement is annulled. For each individual, the amount of total repayment of the loan - the summation term in the expression below is determined by the follow equation:

$$
D=\sum_{y}\left\{\begin{array}{cc}
c r \times w(y), & w(y) \geq T \\
0, & w(y)<T
\end{array}\right\}+A,
$$


where $\mathrm{D}$ is the total income contingent debt incurred by the individual, $c r$ is the contribution rate, $w(y)$ are annual earnings of the individual in year $y, T$ is the earnings threshold, and $A$ is a part of the debt which is annulled if the whole debt is not repaid during the working life. Note that if the debt is not repaid earlier, the collection of the debt may span the entire working life.

In the simulations, the amount of the income contingent debt depends on the following factors:

- Number of years of schooling.

- Targeted proportion of schooling costs covered by tuition (the coverage of 10 to 50 percent was considered in simulations).

- Types of costs included in tuition (current costs only, or current and investment costs).

- Whether the fee is uniform or differentiated so that it reflects the costs of a specific field of study and type of school.

- Interest rate. The simulations consider various interest rates, from positive to negative ones (in the latter case, the real debt decreases - students are subsidized).

The annual repayment of the income contingent loan is determined by the following parameters:

- Debt status. Individuals must make contributions if the debt has not been completely repaid.

- Earnings threshold. Individuals must make contributions if their annual earnings exceed a certain earnings threshold.

- Contribution rate. Consistent with the two above conditions, individuals must pay the prescribed contributions assessed to their annual earnings toward the income contingent tuition debt.

- Individual's annual earnings. This amount, multiplied by the contribution rate, determines the level of the annual repayment in absolute terms. (Note that tuition payments can also be made by full-time students if they are concurrently employed and have sufficiently high earnings). 


\subsection{Data sources}

The simulation cohort is comprised of the cohort of 11,416 full-time students who first enrolled in Slovenian higher education in 1992/93. ${ }^{5}$ We classified all students into four different fields of study (humanities, social sciences, natural sciences, health and other services) and two types of school (2-year and 4-year colleges). ${ }^{6}$ Students' field of study, gender and average study duration is presented in Table 1, and their distribution by age in the year of initial enrollment in Figure 1. As also seen in Table 1, by 2001,4383 of these students graduated with a 4-year diploma, 1885 graduated with a 2-year diploma, and 5148 had not graduated. Table 1 also includes average schooling costs, showing that the costs of the most expensive field of study, Health and Other Services, exceed the costs in the least costly field, Social Sciences, by 270 percent.

The simulation relies on the following information about each individual of the aforementioned cohort:

- College enrollment. For each student of the chosen cohort and for each academic year, we obtained the following data about their enrollment in Slovenian higher educational institutions from 1992 to 2001: year and type of study, school of study, and year of graduation (if they had graduated by 2001). For these students, we also obtained information about their personal characteristics (gender and age). The source of data on college enrollment was the Statistical Office of the Republic of Slovenia.

- Schooling costs per student. The total study costs were calculated from enrollment data during 1992 to 2001 and the annual costs of study in a specific field and type of school (students who have completed coursework and are working on their theses were assigned half of the regular costs). The annual costs of schooling per student, assumed to remain unchanged in real terms during the simulation period, were approximated by the actual costs of schooling per student in 2000 (see the average annual schooling costs per student in Table 2). The source of current costs

\footnotetext{
${ }^{5}$ Some individuals were eliminated from the simulation cohort, namely those for whom data on enrollment for a particular year were missing, and those who were employed during in the 1992-2001 period but for whom insufficient data were available to reconstruct their earnings in each year (7 percent of individuals were eliminated).

${ }^{6}$ In Slovenia, in addition to bachelor's degrees (which require at least 4 years of study), colleges offer associate degrees (which require at least 2 years of study).
} 
per student for 2000 was Slovenian Ministry of Education (investment and other costs were based on official data from 1999-2001).

- Lifelong work history, including data on annual earnings. As explained above, our simulation methodology requires information about the entire, lifelong work history (including earnings) for each student of the cohort. Our data sources provide us with information about the students' work history for the 1992-2001 period. To extrapolate the work history of the simulation cohort beyond the period of observation, we exploited the information about the work history of the whole Slovenian labor force during the period from 1992-2001 to generate a synthetic, lifelong work history for the simulation cohort. For all individuals of the cohort, this work history consists of the beginning and end of each employment spell from the entry into the labor force until the retirement, together with their monthly salary and annual earnings (see below). ${ }^{7}$ The source of the data on each individual's work history from 1992 to 2001 was the Statistical Registry of the Active Population, maintained by the Statistical Office of the Republic of Slovenia, and the source of the data on earnings was the Slovenian Pension Fund. ${ }^{8}$ Individual observations on enrollment, work history and earnings were merged based on common personal identification numbers.

\subsection{Obtaining lifelong work history of the simulation cohort}

Below we explain the procedure of obtaining complete, lifelong work (including earnings) histories for each student included in the simulation cohort. These histories were derived from the histories of the so-called parents - that is, of individuals who were good matches for the individuals of the simulation cohort and for whom data on work history data existed.

As mentioned, the simulation cohort consists of full-time students between the ages of 18 and 27 who first enrolled in one of the Slovenian higher education institutions in the 1992/93 academic year. For these students we obtained both their enrollment data and their work history for 1992-2001 (the so-called "observation interval"). The work history data consisted of starting and ending dates of all

\footnotetext{
${ }^{7}$ Our simulations assume unchanged nominal and real mean earnings in the economy (they are based on the historic 2000 value of the mean yearly gross earnings of 2,048,663 Slovenian Tolars or US\$ 9,664 (1US\$ $=212.1$ Slovenian Tolars).

${ }^{8}$ For details about the data sources, see Haltiwanger and Vodopivec (2003).
} 
employment spells and included earnings data. To obtain a complete work history for the simulation cohort (from the first job until retirement), we extended the work history of each individual of the cohort by the observed, 1992-2001 work history of their "parents." These parents were selected among workers with higher and secondary education who did not attend college during the observation interval. A parent was assigned to each individual from the simulation cohort based the following matching criteria:

- Gender.

- Age; the age of the individual from the simulation cohort at the end of the observation interval (that is, at the end of 2001) must have corresponded to the age of the parent at the beginning of the observation interval (that is, at the beginning of 1992), allowing for a discrepancy of one year.

- Employment status (employed or unemployed).

- Salary (with a $10 \%$ tolerance margin).

- Education (using the groups specified above).

If we could not assign a suitable, unique parent, we allowed the same person to be used as a parent more than once. Of all candidates, only those with the lowest use count were considered, and one was randomly chosen. To prevent systematic errors, no parent was used more than three times (if no candidate parent was found using the above procedure, the individual was removed from the simulation cohort). The gluing procedure was repeated until the simulated individual retired.

Figures 2 to 5 show the age of potential parents in 1992, as well as their employment rate, average monthly salary and annual earning, by gender and field of study, for 1992-2001. Figure 2 shows that the employment rate of parents was reduced, over the span of 10 years, from the rate of about $85-90 \%$ to about 70 percent (note also that the lowest employment rate among all groups was among the dropouts). This reduction mostly reflects older parents leaving the labor force, but includes also any earlier withdrawals from the labor force. The figure shows persuasively that both the level and dynamics of women's employment rates resembles strongly the level and dynamics of men's - a remarkable finding which strong implications for the performance of an income contingent loan scheme. Both monthly and annual earnings show mild real-term increases by age (Figures 4 and5), 
with Social Science graduates consistently recoding posting the highest and dropouts the lowest earnings. Quite remarkably, the earnings of women do not fall short of the earnings of men, a finding which applies to all comparison groups (this again has important implications for the performance of the loan scheme).

Figures 6 to 8 show the employment rate, average monthly salary, and the average annual earnings of the simulation cohort, by gender and field of study and by the year after initial enrollment (annual earnings were calculated as a sum of earnings from all employment spells during the year). Reflecting the characteristics of parents discussed above, employment rates exhibit a sharp increase approximately 5 years after initial enrollment in higher education (except dropouts, whose employment rate is 20 percent already at the time of first enrollment). Employment rates stay in the range of $80-90$ percent from approximately the $10^{\text {th }}$ to the $35^{\text {th }}$ year (for women) and $10^{\text {th }}$ to $40^{\text {th }}$ year (for men) following the higher education enrollment, tapering off gradually beyond that interval. Note that strong reductions in employment rates coincide completely with the average retirement age in Slovenia in the 1990s, and that employment rates of women reflect a 5 year difference in retirement age in their favor (the average retirement age in the 1990s was about 54 years for women, and 59 years for men).

For both men and women, Figures 7 and 8 show a rather steep age-earnings profile. Such profiles are consistent with earnings functions estimates obtained by Orazem and Vodopivec (1997) and Vodopivec (2004). These estimates show that throughout the 1990s, in Slovenia experience commanded a premium which increased nearly linearly with years of service (and therefore age), in line with the regulations of collective agreements, which mandate an automatic wage increase with an increase of work experience.

\section{SIMULATION RESULTS}

This section describes the results of the simulation of the income contingent tuition scheme, applied to the complete cohort of 1992/93 Slovenian students. To repeat, we use ten years of students' historic data (both about their higher education enrollments and work history), and generate their synthetic, lifelong work history as described 
above. Below we present both the results of the base simulation variant as well as deviations from it produced by alternative specifications of the scheme's parameters.

\subsection{Base variant}

Under the base variant, we present simulation results for the benchmark values of the parameters of the income contingent tuition scheme. These values are as follows:

- Tuition cost recovery rate targeted by the income contingent scheme: 20 percent.

- Types of costs included in tuition: only current costs.

- Manner in which tuition is calculated: uniform tuition.

- Interest rate: a real interest rate of zero (with the real debt unchanged).

- Earnings threshold above which payments must be made: average earnings.

- Contribution rate: 2 percent. $^{9}$

These parameters, applied to the Slovenian circumstances and translated to monetary terms, imply an annual tuition of US\$ 484 for public higher educational institutions (see Table 3, where we present also tuition charges under the differentiated tuition system). Moreover, based on historic data, the average 4-year graduate would incur a total income contingent debt of US\$2,502, and the average annual repayment would be US\$297. Note that the average gross earnings of individuals repaying debt would be 54 percent higher than the Slovenian average, that is, US\$ 14,875 (all in 2000 prices and using the average 2000 exchange rate of 1US\$=212.5 Slovenian Tolars).

We focus the discussion on the following performance indicators of the scheme: the amount of schooling costs covered by the tuition, the number of years after enrollment before the income contingent tuition is repaid, the proportion of people who would not repay any of their debt, and the average earnings of those repaying the income contingent tuition. ${ }^{10}$

Table 4 presents the summary results of the base variant, focusing on the state of the scheme 20 years after its implementation (20 years after enrollment); Figures 9-

\footnotetext{
${ }^{9}$ The parameters roughly correspond to the ones under the Australian Higher Education Contribution Scheme in its initial stage of introduction (see Chapman, 1997).

${ }^{10}$ For some of the calculations, we examine the characteristics of the income contingent tuition scheme in different periods after its implementation. The assumption underlying these calculations is that the number of newly enrolled students remains constant at the 1992/93 academic year level - 11,496. Under the base variant, this implies a steady state of 47,222 students and 69,176 individuals making annual repayments.
} 
19 present the results for a broader domain of values for the scheme's parameters. Table 4 also presents the average tuition figures for the entire schooling period for each type and field of study. As is evident from the table, the amount of tuition each group is charged varies much less than the actual costs of schooling presented in Table 1 (because the base variant is based on a uniform tuition, the differences in tuition between groups arise only because of differences in study duration).

Schooling cost recovery rate. The income contingent tuition scheme yields little revenue in the first 5-7 years after its implementation since individuals have yet to take on the burden of the debt and few (especially those who drop out) begin to repay (Figure 9). ${ }^{11}$ The simulations also show, however, that 20 years after its introduction, the scheme would already cover 14 percent of higher education costs, and after 35 years - upon reaching maturity - 17.3 percent. Note that, of course, these results assume a 20 percent target cost recovery, and that a larger cost recovery target yields greater actual cost coverage.

When we compare the cost recovery by type and field of study, our base variant simulation offers some surprising results. Especially notable is a disproportionally large cost recovery rate in the social sciences, a result attributable to the fact that all study fields are charged the same tuition. Namely, under a uniform tuition rate, students in the social sciences - the field of study with the lowest per student costs and the highest earnings - bear the largest relative tuition burden, which pushes their cost recovery rate far above the average. On the other hand, under a uniform tuition scheme Health and Other Services (a relatively expensive and lengthy field of study) have the smallest cost recovery rate and are therefore the field most subsidized by others. It is also surprising that there is little difference in cost recovery between men and women - in fact, 20 years after implementation and later, women cover more of their tuition costs than men (Figure 9).

Debt repayment. One of the crucial indicators of the viability of the income contingent tuition scheme is its repayment performance. The simulations show that under the base variant - that is, under a modest, 2-percent repayment rate - 55 percent of individuals repay their entire debt within 20 years, and 73 percent within 30 years

\footnotetext{
${ }^{11}$ In the Australian case, students are offered an option to pay the tuition upon enrollment with a 25 percent discount, which somewhat accelerates the dynamics of the repayment process (but in the past, the majority of Australian students decided to postpone their payments; see Chapman, 1997).
} 
(Figure 10). For the group with a 4-year college degree, the repayment rate is even higher ( 70 percent repay their debt within 20 , and 87 percent within 30 years); in contrast, for those with 2-year college degree and particularly for students who have not finished their studies, the repayment rate is lower. The results also differ by field of study: the Social sciences come first in terms of the highest full repayment rate, followed by the Natural sciences, then Health and other services, with the Humanities in last place (because the simulation assumed a uniform tuition scheme, the results mostly reflect differences in study duration and payers' salaries). It is interesting to note that in terms of the percentage of fully repaid debt, men surpass women, but the difference decreases as the period of repayment lengthens. In contrast, simulations of Barr and Crafward (1988) show markedly worse repayment performance of women than men. ${ }^{12}$

The simulation yields similar results for the proportion of individuals who repay at least half of their debt (Figure 11), except that in this case the percentages are higher. For example, 30 years after enrollment, over 80 percent of individuals repay half of their debt; and among those with a 4-year college degree, this percentage exceeds 95 percent.

Another interesting aspect of the debt repayment performance of the scheme is the proportion of individuals who do not repay any debt. As expected, this percentage falls significantly between the $7^{\text {th }}$ and $15^{\text {th }}$ years after enrollment (Figure 12). However, after 20 years, 19 percent of individuals still do not repay any of their debt, and after 30 years, 10 percent. Consistent with the above results, the proportion of non-payers is the smallest among those with 4-year college degrees (virtually no differences exist in this category among different fields of study) and is the greatest among those who did not graduate. Interestingly, the proportion of women who do not repay any debt consistently exceeds the proportion of men by 3-5 percentage points (except about 13-16 years after initial enrollment, when they are same).

As discussed above under the schooling cost recovery rate, at a 20 percent target cost recovery rate, the "leakage" of the scheme due to uncollected debt is 2.7 percentage points, or approximately 13.5 percent of total lending (see further results

\footnotetext{
${ }^{12}$ Assuming modest real earnings growth over the life cycle and a zero interest rate (the variant corresponding to our simulations), Barr and Crawford estimate the repayment rate of 87.1 and 67.6 percent for men and women, respectively.
} 
under the sensitivity analysis below). The implied student "default rate" is thus about 13.5 percent, substantially lower than 21 percent default rate as reported by Barr and Crawford (1998) for the UK, obtained under a similar simulation exercise. The better repayment performance of Slovenian women is probably the most important factor in explaining this difference.

\section{Average earnings of individuals repaying income contingent tuition.}

Under the base variant, the threshold above which payments are mandated is set at the level of the average economy-wide earnings. It is interesting to examine the average earnings of individuals exceeding this threshold and repaying their debt. Consistent with an increasing age-earnings profile, the earnings of individuals repaying their debt increase in the first years after the scheme's introduction. After a certain period, however, one can expect the average earnings of individuals repaying debt to level off, as the positive impact on the average earnings coming from gaining work experience of the generation of debt payers is nullified by the opposite effect coming from the individuals who start to repay their debt (because they start their careers, their wages are relatively low) and from the individuals who repay all their debt and thus leave the scheme. Simulations show the average earnings of those repaying their debt indeed continue to grow until the $15^{\text {th }}$ year after the implementation of the scheme, after which they level off at 154 percent of economy-wide average (Figure 13). It follows that even at a relatively low earnings threshold of the base variant, the earnings of the individuals repaying the income contingent tuition would be considerably above-average.

\subsection{Sensitivity analysis}

The above results show the functioning of the income contingent tuition scheme under the predetermined, benchmark values of its parameters. In what follows we discuss how changing the scheme parameter influences two key aspects of the income contingent tuition scheme: the proportion of individuals who completely repay their debt (by tracking down the proportion which evolves after 20 years from the initial enrollment), and the cost recovery rate (by tracking down the rate which occurs after 20 years from the scheme's introduction). The impact of parameters changes on the average earnings of individuals repaying the debt is small and thus will not be discussed. It should be noted that in performing the scheme's sensitivity analysis in 
regard to a specific parameter, only that parameter is modified while all others retain their benchmark value.

Variations in the target tuition cost recovery rate strongly influence both the proportion of individuals who completely repay their debt and the cost recovery rate. Targeted cost recovery rates of 40-50 percent dramatically decrease the percentage of individuals who repay their debt 20 years after initial enrollment (this is especially true for graduates in the Humanities, where practically nobody repays his/her entire debt within this period - see Figure 14). This means that at a given contribution rate, higher tuition costs lengthen the debt repayment period. By the same token, the cost recovery rate increases significantly - for example, at a 50 percent target cost recovery rate, the actual recovery rate 35 years after the scheme's introduction is 37 percent (Figure 14). As expected, the marginal impact of the increase in the target tuition cost recovery rate increases markedly in later periods, starting from approximately 15 years after its introduction).

The influence of including investment costs in the costs of schooling is less dramatic (Figure 15). Both the proportion of individuals who repay their debt in 20 years and also the cost recovery rate decrease, but only moderately. Note that investment costs represent an addition of 13 percent to the recurrent schooling costs see Table 2.

Changes of the contribution rate also have an important impact on the performance of the income contingent loan scheme. As expected, increasing the contribution rate increases both the proportion of those who repay all of their tuition within 20 years as well as the cost recovery rate (Figure 16). Note, however, that this effect is strongly nonlinear and that the marginal effect of raising the contribution rate beyond three percent is very small. As a result, setting the contribution rate higher than 3 percent may be imprudent, because the costs to those forced to repay their debt at a younger age may outweigh the benefits of the scheme"s better repayment performance (this is true assuming a target cost recovery rate of about 20 percent).

Variations in the contribution rate also help identify the limits of efforts to reduce the default rate of income contingent loans. As shown in Figure 16, the longterm schooling cost recovery rate (the recovery rate which occurs 35 years after the scheme's introduction, that is, when the scheme reaches maturity) at a 3 percent 
contribution rate is 18 percent, and at 5 percent, it is 18.4 percent - all assuming a 20 percent target cost recovery rate. Raising the contribution rate to 3 percent thus reduces the long-term leakage of the system to 10 percent of total lending, and raising it to 5 percent reduces it to 8 percent of total lending. In other words, at a 20 percent target cost recovery rate, the implied student default rate can be as low as 10 percent (at a 3 percent contribution rate) and even 8 percent (at a 5 percent contribution rate).

The influence of the earnings threshold is also nonlinear. Lowering the earnings threshold below 100 percent of average earnings increases the proportion of people who completely repay their tuition within 20 years, but not dramatically; increasing it, however, more strongly reduces this proportion (Figure 17). Consistent with these results, a low earnings threshold does not significantly increase the cost recovery rate: decreasing the earnings threshold from 100 percent to 50 percent of mean earnings in the economy increases the recovery rate 35 years after its introduction by a mere 2 percentage points. Note, however, that lowering the earnings threshold can contribute to lowering the implied default rate of the scheme - for example, the earnings threshold set at 75 percent of mean earnings in the economy implies a 7 percent long-term default rate.

The interest rate applied to income contingent debt is also important. While a negative real interest rate (implying government subsidies to debt holders) increases the proportion of those who repay their debt after 20 years, it also heavily decreases the cost recovery rate (Figure 18). Interestingly, a negative real interest rate especially accelerates the repayments of 4-year college graduates. Even more dramatic are the effects of introducing a positive real interest rate - this significantly lengthens the repayment period and thus contributes to a much greater cost recovery rate.

Especially intriguing is the effect of introducing a differentiated tuition rate instead of a uniform one, thus avoiding cross-subsidization among different fields of study (with the uniform tuition, students in the fields with the lower schooling costs subsidize the rest). In Table 3 we present the tuition charges under the differentiated tuition system, with each charge based on the average costs for a particular field of study. Simulations indicate that holding other parameters unchanged, introducing a differentiated tuition scheme decreases the cost recovery rate (Figure 19). This means that the increase in the repayments by those whose tuition, and thus debt, increases 
(mainly graduates in the fields of Health and Other Services, Natural Sciences, and also the Humanities) does not make up for the decrease in repayments by those whose tuition, and thus debt, decreases (graduates of the Social Sciences, see Table 3). Introducing differentiated tuition thus decreases the payment obligations of those who are well-paid (mainly Social Sciences graduates) and increases the obligations of those who with lower earnings (especially the Natural Sciences and the Humanities see Figure 8). Indeed, the proportion of those who repay their debt within 20 years increases among Social Science and 2-year college graduates but decreases significantly among other groups (see Figure 19).

\section{CONCLUDING REMARKS}

The simulation results show that an income contingent loan scheme to partly recover tuition costs in higher education would be well-suited to Slovenia - and, arguably, to other European transition countries. ${ }^{13}$ The scheme would substantially increase the resources available for higher education, while it would only "tax" the wealthy and only marginally decrease the current earnings of those repaying the loan. Moreover, the financial performance of the scheme would be solid, with a debt default rate of about 20 percent, and under certain circumstances even below 10 percent. The simulations also show that labor market conditions matter: because of their stronger attachment to the labor force, the repayment performance of women in Slovenia would be better than in the UK, which has important implications for the financial performance of the whole scheme. It should be added that the above simulations do not consider changes in the behavior of students and thus underestimate the financial performance of the scheme. It is only reasonable to expect that the introduction of such scheme would shorten the average study duration and increase the graduation rate - an effect which may be significant provided that the previous system did not charge tuition. ${ }^{14}$

\footnotetext{
${ }^{13}$ In comparison to OECD countries, Slovenia shares with other transition countries relatively high women labor force participation rates as well as a relatively low women's pay gap. Slovenia's employment rate in the 1990s was comparable to those in other transition countries, but its unemployment rate was on the low side, and so was the relative unemployment rate of workers with tertiary education (World Bank, 2003).

${ }^{14}$ Students would have a financial incentive to make better use of their study time, and students without serious intentions to graduate would have less incentives to enroll. Ad-hoc evidence about the second point is provided by the College of Electrical Engineering of the University of Ljubljana. The College
} 
The simulations also offer valuable guidance about shaping income contingent loan schemes in transition countries. Assuming a target cost recovery rate of 20 percent, our benchmark parameters represent suitable values for a scheme aimed at partial recovering tuition costs (that is, ignoring student income support). The simulations also suggest that at a larger target cost recovery rate, a higher, perhaps 3 or 4 percent contribution rate may be needed. Furthermore, subsidizing the interest rate (for example, allowing the real interest rate to be negative) is not warranted - it decreases the cost recovery rate, particularly by easing debt repayment of individuals with high earnings. And simulations speak in favor of setting a relatively high repayment threshold, say equal to the mean economy-wide earnings.

Important unresolved questions remain, however. For example, the discretion of universities over setting a tuition would improve allocative efficiency (Barr, 2001). Our simulations suggest, however, that differentiated tuition charges impair the financial performance of income contingent loan scheme (they worsen the general cost recovery rate because they tend to decrease the accrued debt of graduates with highest earnings: graduates in the social sciences). There are also important factors which remained beyond the scope of the current investigation. Above all, the informal economy and emigration, two important potential channels of the financial leakage of the scheme, were not explored.

Despite their general attractiveness, country-specific circumstances, particularly the capacity of the country to administer such a scheme, importantly determine the suitability of an income contingent loan scheme for a specific country. In European transition economies, it seems that many of prerequisites for effective administration exist: (i) in all countries, individuals have unique personal identification numbers which are used either for taxation or social security purposes, or both (the exception is Hungary - the use of such a number was banned in the early 1990s by the Constitutional Court - where individuals possess different identification numbers for taxation and social security purposes); (ii) in most countries record keeping of tax-returns and social security contributions is done via electronic media;

has a large enrollment of "dead souls:" in 1999/2000 school year, 50 percent of newly enrolled students in their 2-year program did not complete a single examination, and 24 percent in the 4-year program did the same. Only 2 percent of students in the 2-year program, and only 16 percent of students in the 4-year program, completed all their exams on schedule (Zupančič, Bajd and Smole, 2001). 
and (iii) tax/contribution collection is reasonably reliable (except in Russia, Romania, and Ukraine). By piggybacking on existing information and taxation systems, these countries could introduce an income contingent loan scheme with minimal costs. ${ }^{15}$ With the pressing need for mobilizing more higher education resources created by the large increase of student enrollments in the 1990s, it seems that the decision to introduce such a scheme is largely a political economy issue.

\footnotetext{
${ }^{15}$ In Slovenia, for example, the Ministry of Finance would build a database that would set up a unique account for every student. Personal information about students could be obtained from a taxation database; in addition, such an account would maintain records about the amounts of the loan taken and about the repayments. Information about the increases of the loan would be provided by the Ministry of Education, based on administrative records about yearly higher education enrollments. To administer tuition repayments, Ministry of Finance would process the information from annual personal income tax returns (inferring whether the individual's earnings exceed the predetermined earnings threshold), calculate the annual repayment, and add it to the tax obligation. Calculations show that the costs of implementing the income contingent loan scheme in Slovenia would be very small and would amount to 0.48 percent of collected debt - substantially less than in Australia. The calculations of the magnitude of the implementation costs are based on estimates of current annual expenses of collecting tuition of 19.1 million SIT and annual tuition collected in the order of 3.965 billion SIT (the calculations are based on the base variant of deferred tuition, as detailed above, and under the assumption that the number of students in Slovenia would remain constant at around 77,000 - for details, see Vodopivec et al, 2002).
} 


\section{REFERENCES}

Barr, Nicholas (2001). "The Welfare State as Piggy Bank. Information, Risk, Uncertainty, and the Role of the State." Oxford University Press.

Barr, Nicholas and Iain Crawford (1988). "Funding Higher Education in an Age of Expansion.” Education Economics, Vol. 6 (1), pp. 45-70.

Chapman, Bruce (1997). "Conceptual Issues and the Australian Experience with Income Contingent Charges for Higher Education.” The Economic Journal, May, pp. 738-751.

Chapman, Bruce (2003). "Income Contingent Loans for Higher Education. International Reform.” The World Bank, processed.

Haltiwanger John and Milan Vodopivec (2003). Worker Flows, Job Flows and Firm Wage Policies: an Analysis of Slovenia. Economics of Transition, Vol. 11 (2) 2003, pp.253-290.

Kraft, Evan and Milan Vodopivec (2003). "The New Kids on the Block: The Entry of Private Business Schools in Transition Economies." Education Economics, 11 (3): 239-257.

Mramor, Dušan (2001). "Funding Higher Education." In "Development of Higher Education in Slovenia," Slovenian Academy of Sciences and Arts, Ljubljana, November 2001, pp. 275-284.

Orazem, Peter in Milan Vodopivec (1997). "Value of Human Capital in Transition to Market: Evidence from Slovenia." European Economic Review, Vol. 41, str. 893-903.

Rutkowski, J. 2001. "Wage Inequality in Transition Economies of Central Europe. Trends and Patterns in the Late 1990s." Social Protection Discussion Paper Series 0117. World Bank, Washington, D.C.

Vodopivec, Milan (2004). "Labor Market Developments in the 1990s.” In M. Mrak, M. Rojec and C. Silva-Jauregui (eds.), Slovenia: From Yugoslavia to the European Union, Washington, DC: The World Bank, 292-314.

Vodopivec, Milan, Sergij Gabršček, Bojan Grošelj Viljem Pšeničny (2002). “An Introduction of Income Contingent Tuition Scheme in Slovenian Higher Education." GEA College of Entrepreneurship, processed .

World Bank (1994). "Higher Education: Lessons Of Experience.” Washington, DC: World Bank.

World Bank (2003). The Labor Market Performance of Transition Countries: Recent Developments, World Bank: Human Development Network. 
Zupančič, Borut, Tadej Bajd in Franc Smole (2001). "Problems of Students in Sciences." In "Development of Higher Education in Slovenia," Slovenian Academy of Sciences and Arts, Ljubljana, November 2001, pp. 225-230. 
Table 1: Number, average study duration, and study costs of the Slovenian 1992/93 student cohort

\begin{tabular}{|c|c|c|c|}
\hline & $\begin{array}{l}\text { Number of } \\
\text { students }^{1}\end{array}$ & $\begin{array}{c}\text { Average study } \\
\text { duration } \\
\text { (in years) }\end{array}$ & $\begin{array}{l}\text { Average } 2000 \\
\text { study costs } \\
\text { (in US\$) }^{2}\end{array}$ \\
\hline \multicolumn{4}{|l|}{ A. Field and type of study } \\
\hline 4-year graduates & 4,383 & 5.7 & 13,691 \\
\hline Humanities & 1,090 & 5.7 & 15,575 \\
\hline Social sciences & 1,715 & 5.5 & 7,589 \\
\hline Natural sciences & 944 & 5.8 & 18,089 \\
\hline Health and other services & 634 & 6.1 & 20,406 \\
\hline 2-year graduates & 1,885 & 4.0 & 7,232 \\
\hline Dropouts & 5,148 & 2.8 & 6,315 \\
\hline \multicolumn{4}{|l|}{ B. Gender } \\
\hline Men & 4,985 & 4.0 & 9,243 \\
\hline Women & 6,431 & 4.3 & 9,341 \\
\hline Total & 11,416 & 4.1 & 9,298 \\
\hline
\end{tabular}

Notes:

${ }^{1}$ Number of full-time students who first enrolled in the 1992/93 academic year.

${ }^{2}$ Using the 2000 average exchange rate of 1 US $\$=212.1$ Slovenian Tolars. 
Table 2: Average annual schooling costs per student $\left(2000\right.$, in US\$) ${ }^{1}$

\begin{tabular}{|c|c|c|}
\hline & \multicolumn{2}{|c|}{ Types of costs included } \\
\hline & Only current costs ${ }^{2}$ & $\begin{array}{l}\text { Including investment } \\
\text { costs }^{3}\end{array}$ \\
\hline \multicolumn{3}{|l|}{ A. Four year colleges } \\
\hline Total $^{4}$ & 2,851 & 3,221 \\
\hline Humanities & 3,047 & 3,418 \\
\hline Social Sciences & 1,400 & 1,770 \\
\hline Natural Sciences & 3,484 & 3,855 \\
\hline Health and Services & 3,986 & 4,357 \\
\hline B. Two year colleges & 1,536 & 1,736 \\
\hline
\end{tabular}

Source: Own calculations based on data from Slovenian Ministry of Education of average per student costs by institution.

Remarks:

${ }^{1}$ Included is the number of full-time students who are enrolled in the month of September prior to the year to which costs pertain. See Table 1 for the exchange rate.

${ }^{2}$ Government's higher educational costs (in the calendar year). They cover salaries (which typically represents 90 percent of all costs), material costs, part of equipment costs, lump sums intended for professor, assistant, and intern research pay, and university administration costs.

${ }^{3}$ Assuming that investments and other similar costs amount to 13 percent of current costs per student (the estimate is based on the proportion of investment and other similar costs in budgetary funds in the years 1999, 2000, 2001, Official Gazette of the Republic of Slovenia, No. 20, March 8, 2002, p. 1523).

${ }^{4}$ Weighted average (by the number of students in a group). 
Table 3: Amount of uniform and differentiated tuition $(2000 \text {, in US } \$)^{1}$

\begin{tabular}{|l|c|c|}
\hline & \multicolumn{2}{|c|}{ Types of costs included in tuition ${ }^{2}$} \\
\hline & Only current costs & $\begin{array}{c}\text { Including investment } \\
\text { costs }\end{array}$ \\
\hline A. Uniform annual tuition & 484 & 550 \\
\hline \multicolumn{2}{|c|}{} \\
\hline B. Differentiated annual tuition \\
\hline Humanities & 609 & 684 \\
\hline Social Sciences & 280 & 354 \\
\hline Natural Sciences & 697 & 771 \\
\hline Health and Services & 797 & 871 \\
\hline 2-year colleges & 307 & 347 \\
\hline
\end{tabular}

Source: Own calculations based on data from Slovenian Ministry of Education of average per student costs by institution.

Remarks:

${ }^{1}$ Assuming a 20 percent cost coverage rate. The uniform tuition figure thus represents 20 percent of the average schooling costs in all schools, and the differentiated tuition figure represents 20 percent of the average schooling costs in a certain group of schools. See Table 1 for the exchange rate.

${ }^{2}$ See the remarks of Table 2 for the types and calculation of investment costs. 
Table 4: Simulation results, base variant ${ }^{1}$

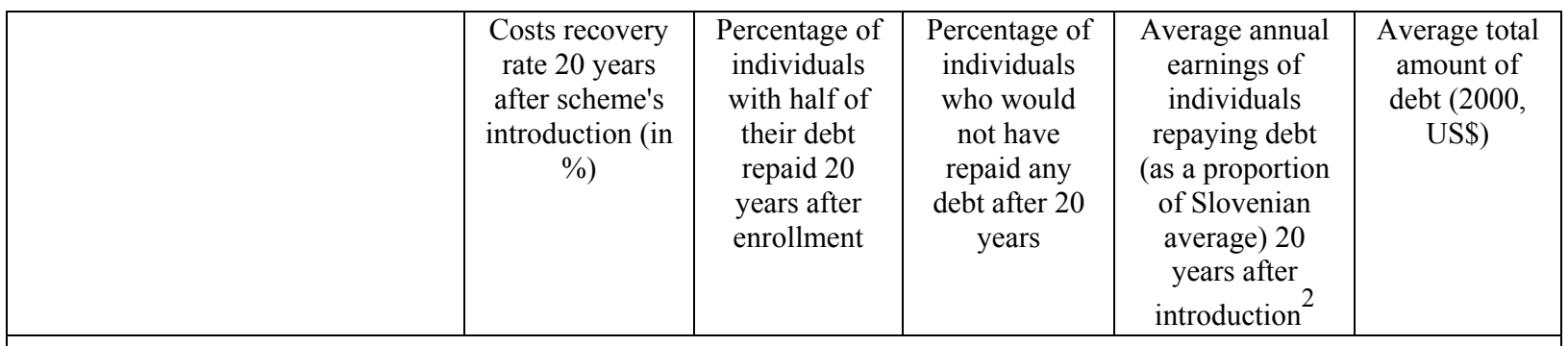

\section{A. Field and type of study}

\begin{tabular}{|c|c|c|c|c|c|}
\hline 4-year colleges & 15.0 & 66.2 & 5.7 & 1.67 & 2,502 \\
\hline Humanities & 12.0 & 54.1 & 7.6 & 1.41 & 2,489 \\
\hline Social Sciences & 27.5 & 77.8 & 4.9 & 1.81 & 2,425 \\
\hline Natural Sciences & 11.4 & 62.1 & 5.6 & 1.72 & 2,547 \\
\hline Health and Services & 10.9 & 61.8 & 4.6 & 1.72 & 2,667 \\
\hline 2-year colleges & 18.5 & 57.3 & 11.3 & 1.39 & 1,839 \\
\hline Dropouts & 10.0 & 45.2 & 33.4 & 1.30 & 1,320 \\
\hline \multicolumn{6}{|l|}{ B. Gender } \\
\hline Men & 13.8 & 57.9 & 17.8 & 1.57 & 1,796 \\
\hline Women & 14.0 & 53.2 & 20.2 & 1.49 & 1,909 \\
\hline Total & 13.9 & 55.3 & 19.1 & 1.52 & 1,860 \\
\hline
\end{tabular}

${ }^{1}$ The values of the simulation coefficients in the base variant are as follows:

- Contribution rate and base: 2 percent of annual income.

- Uniform tuition.

- 20 percent target proportion of study costs to be covered by tuition.

- Only current expenses are included.

- A real interest rate equal to zero.

- Earnings threshold above which payments must be made: average annual earnings in Slovenia.

${ }^{2}$ The average annual gross income of the employed, included in the simulations, is 2,048,663, and their average monthly gross salary, 175,937 (in 2000 SIT). 
Figure 1: Distribution of the simulation cohort by age at initial enrollment

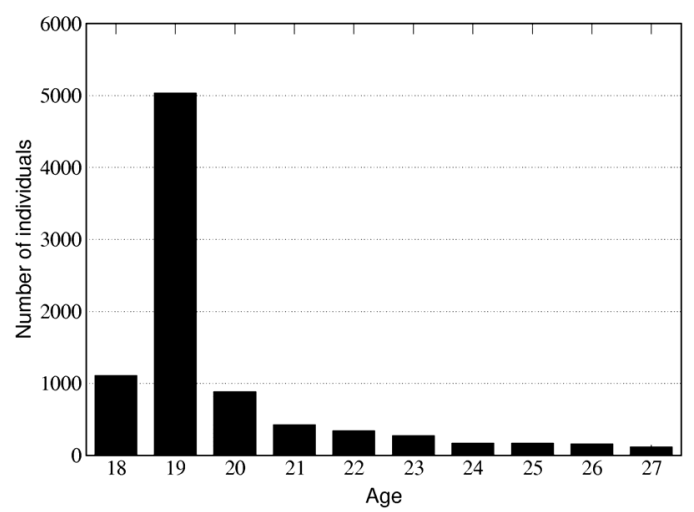

Figure 2: Age of parents, by gender and the field of study (1992)
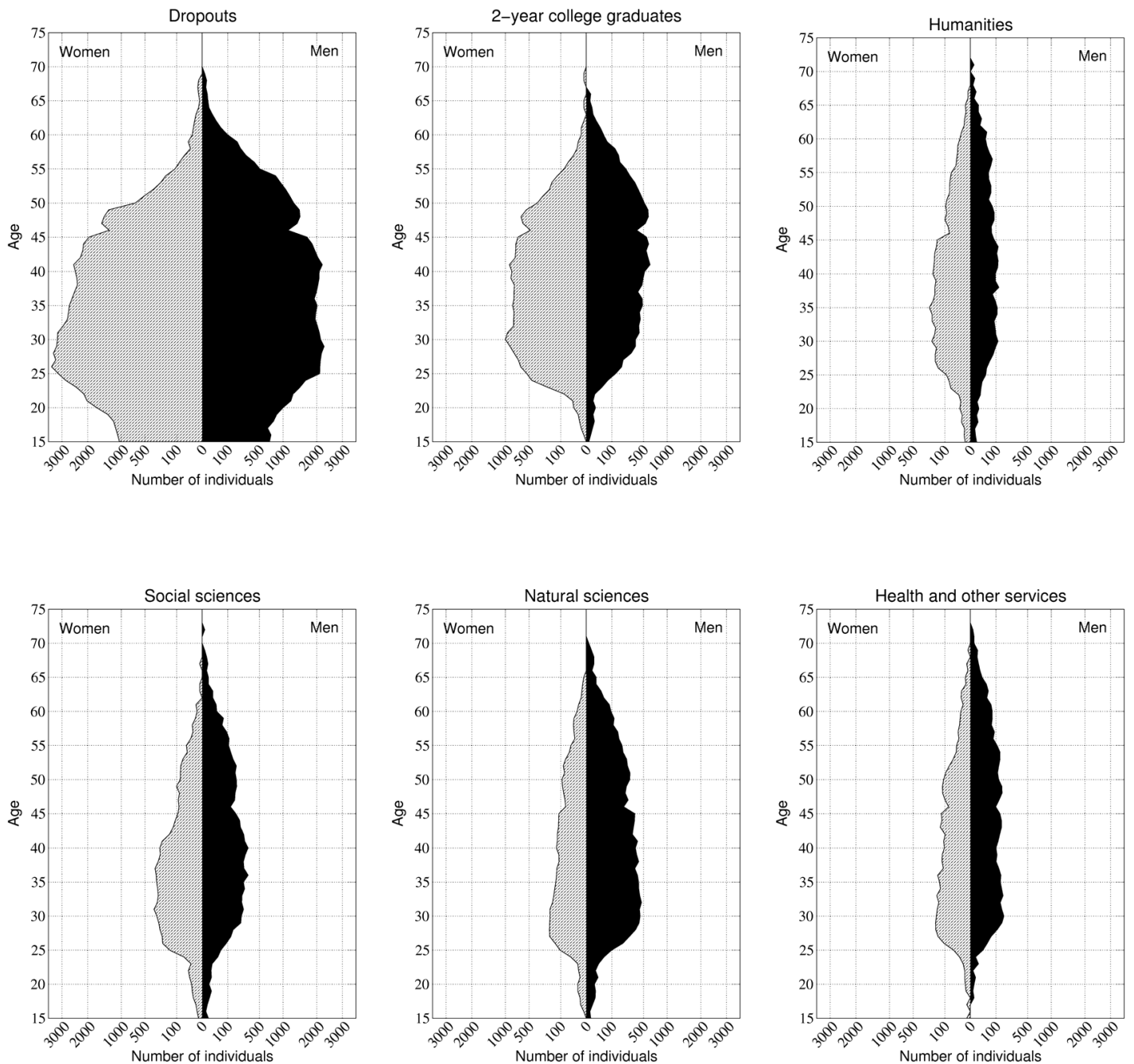
Figure 3: Employment rate of parents, by gender and the field of study (in percent), 1992-2001
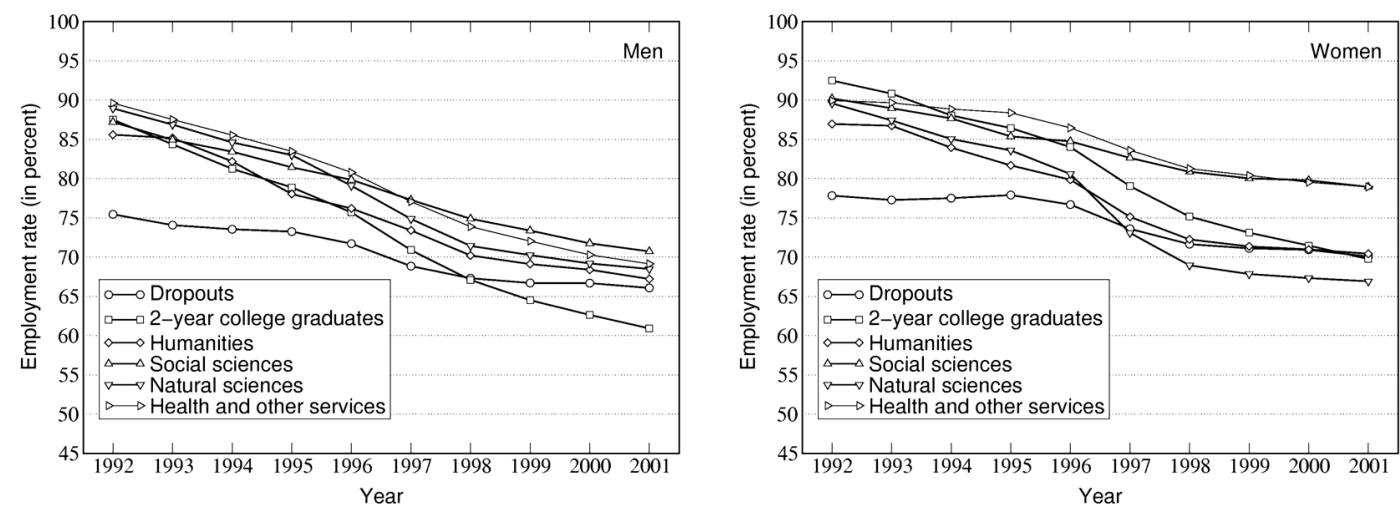

Figure 4: Average monthly earnings of parents, by gender and the field of study, 19922001 (as a proportion of the economy-wide average)
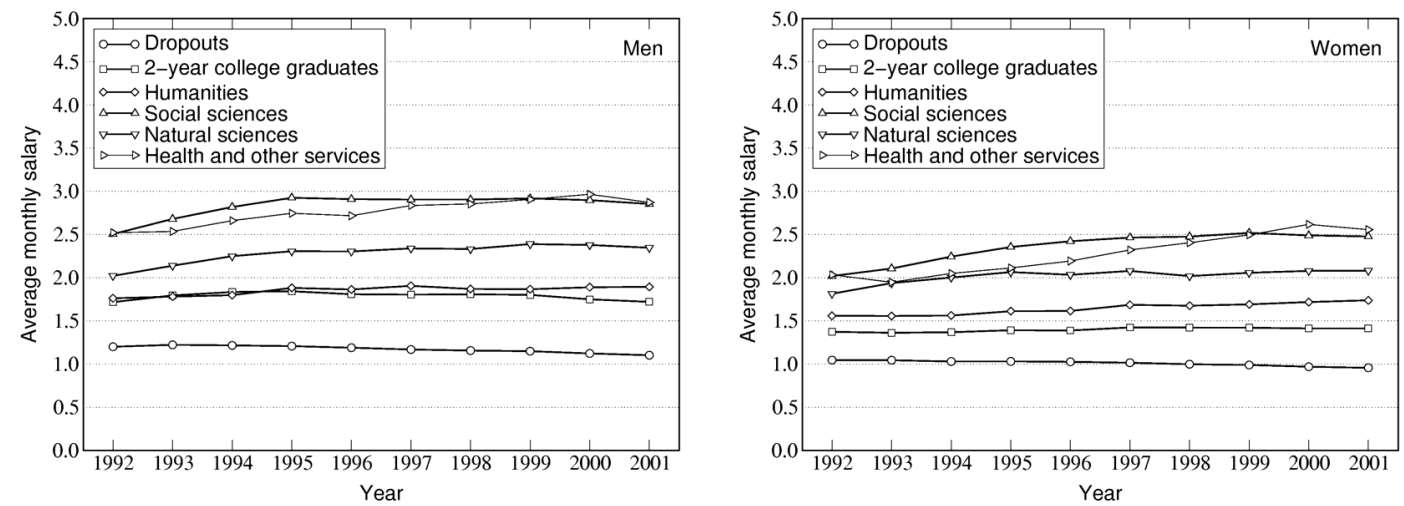

Figure 5: Average annual earnings of parents, by gender and the field of study, 19922001 (as a proportion of the economy-wide average)
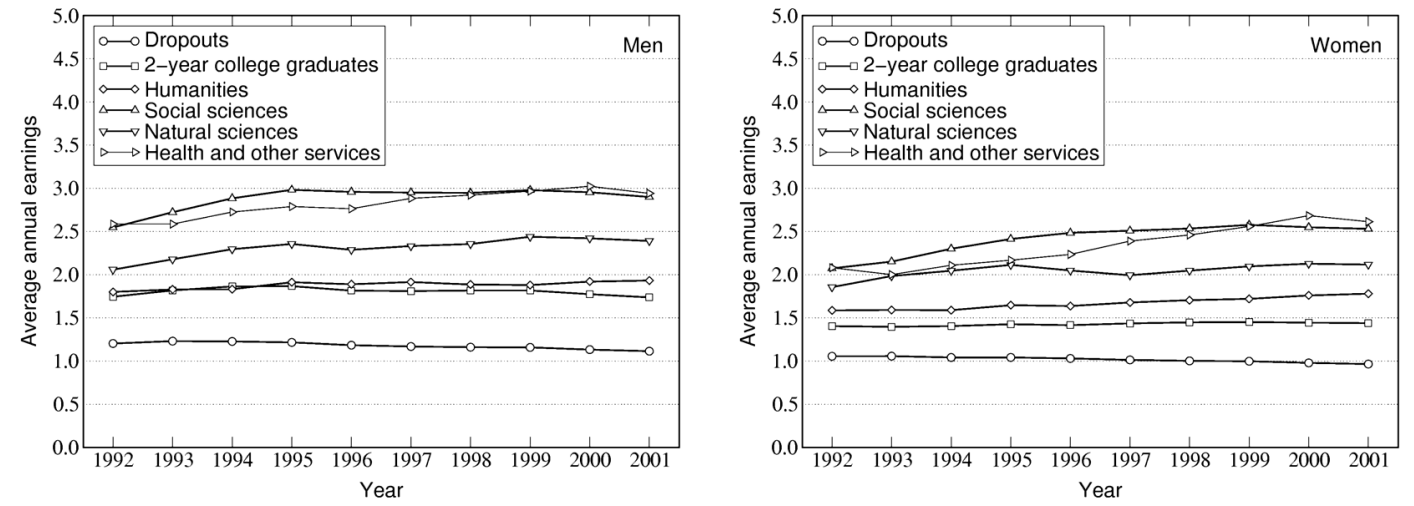
Figure 6: Employment rate of the simulation cohort, by gender, the field of study and number of years after initial enrollment
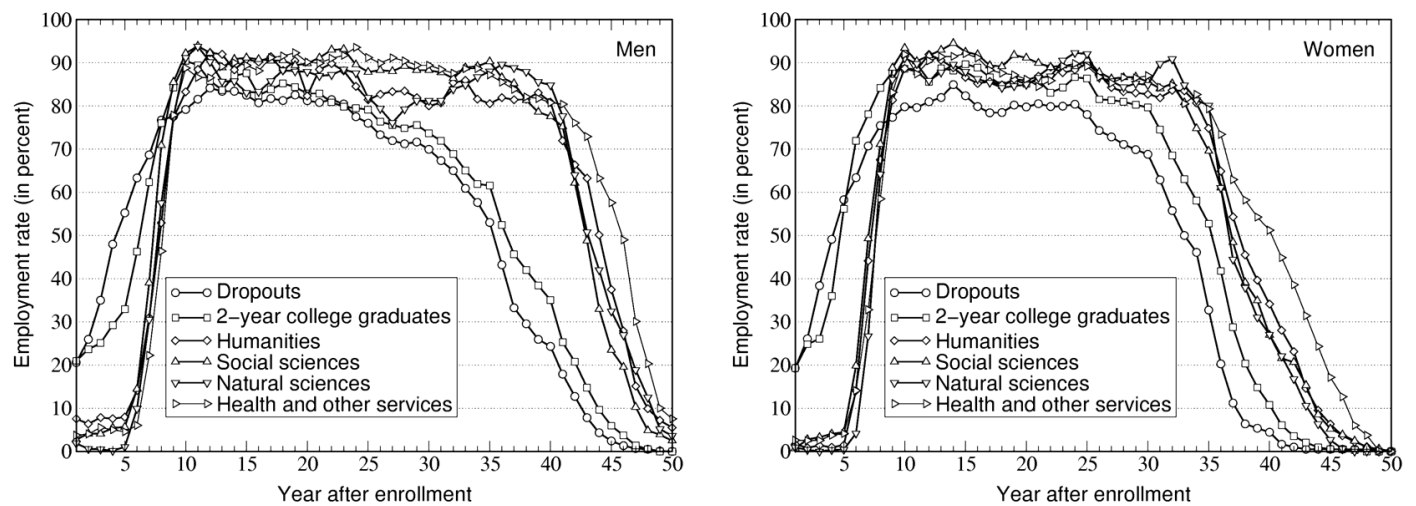

Figure 7: Average monthly earnings of simulation cohort, by gender, the field of study and number of years after initial enrollment (as a proportion of the economy-wide average)
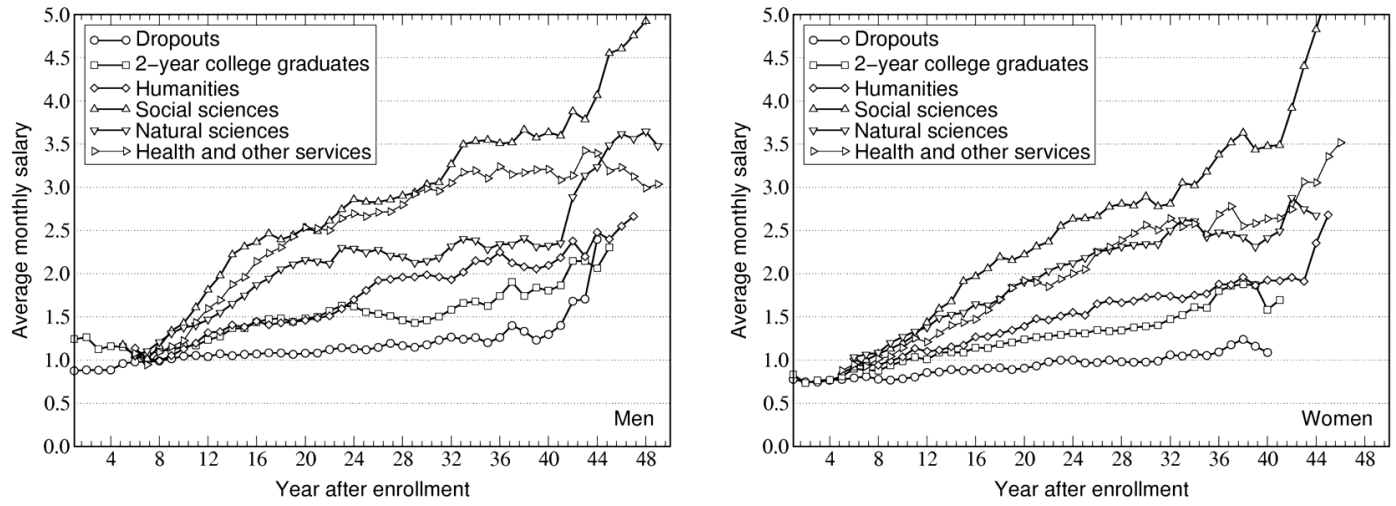

Figure 8: Average annual earnings of simulation cohort, by gender, the field of study and number of years after initial enrollment (as a proportion of the economy-wide average)
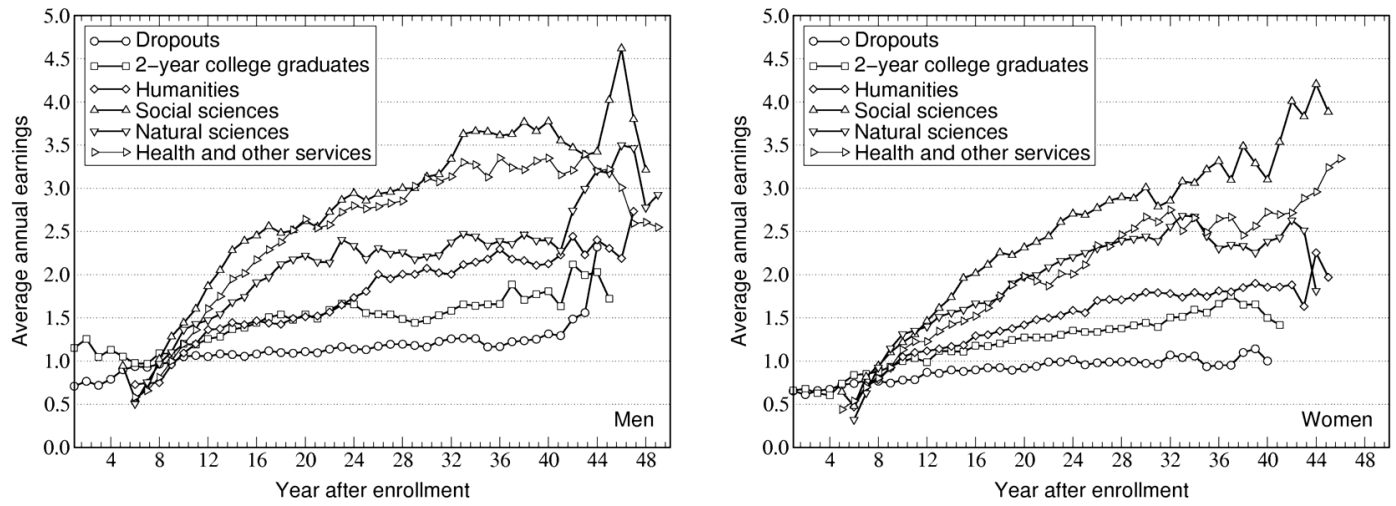

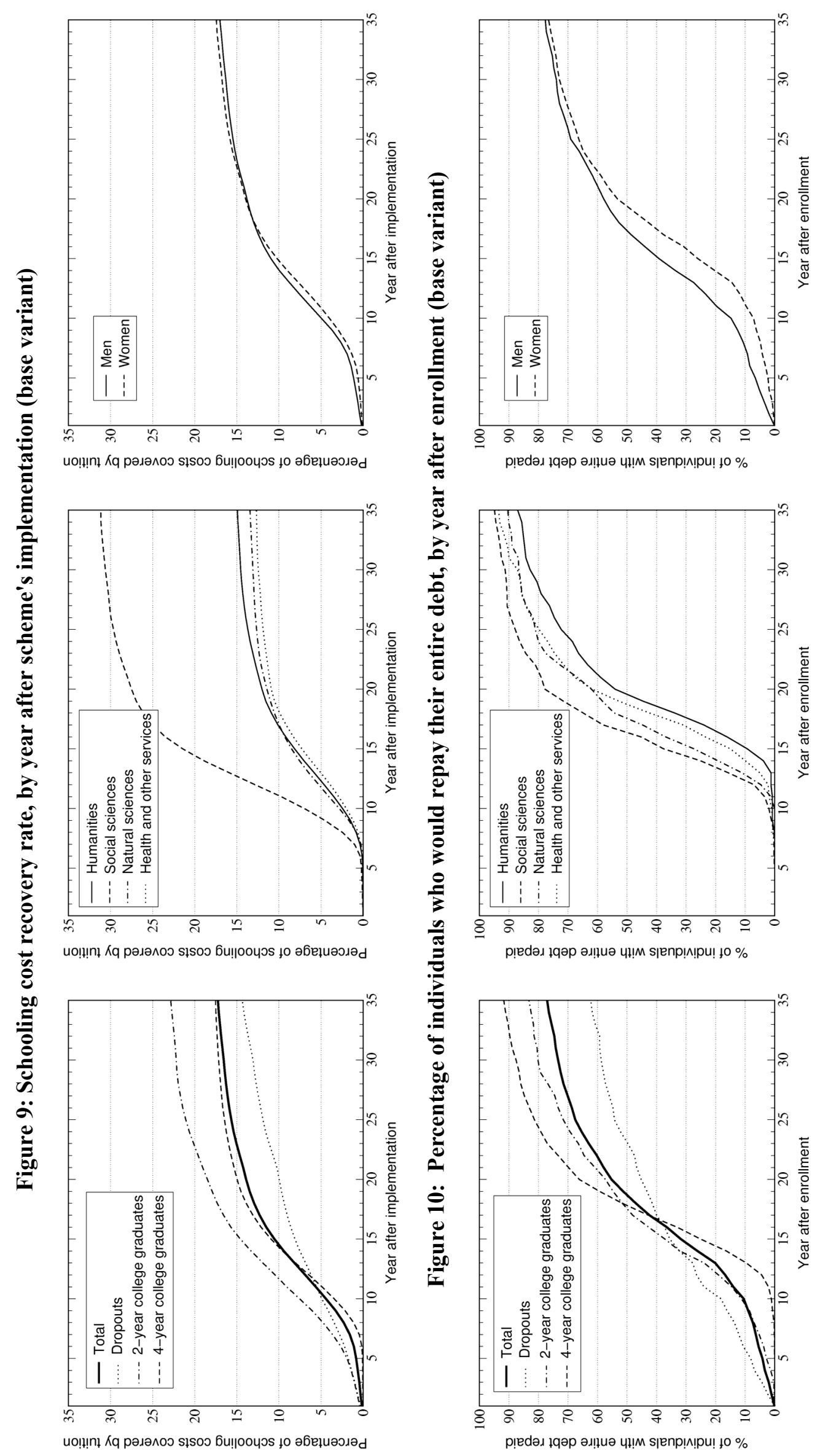

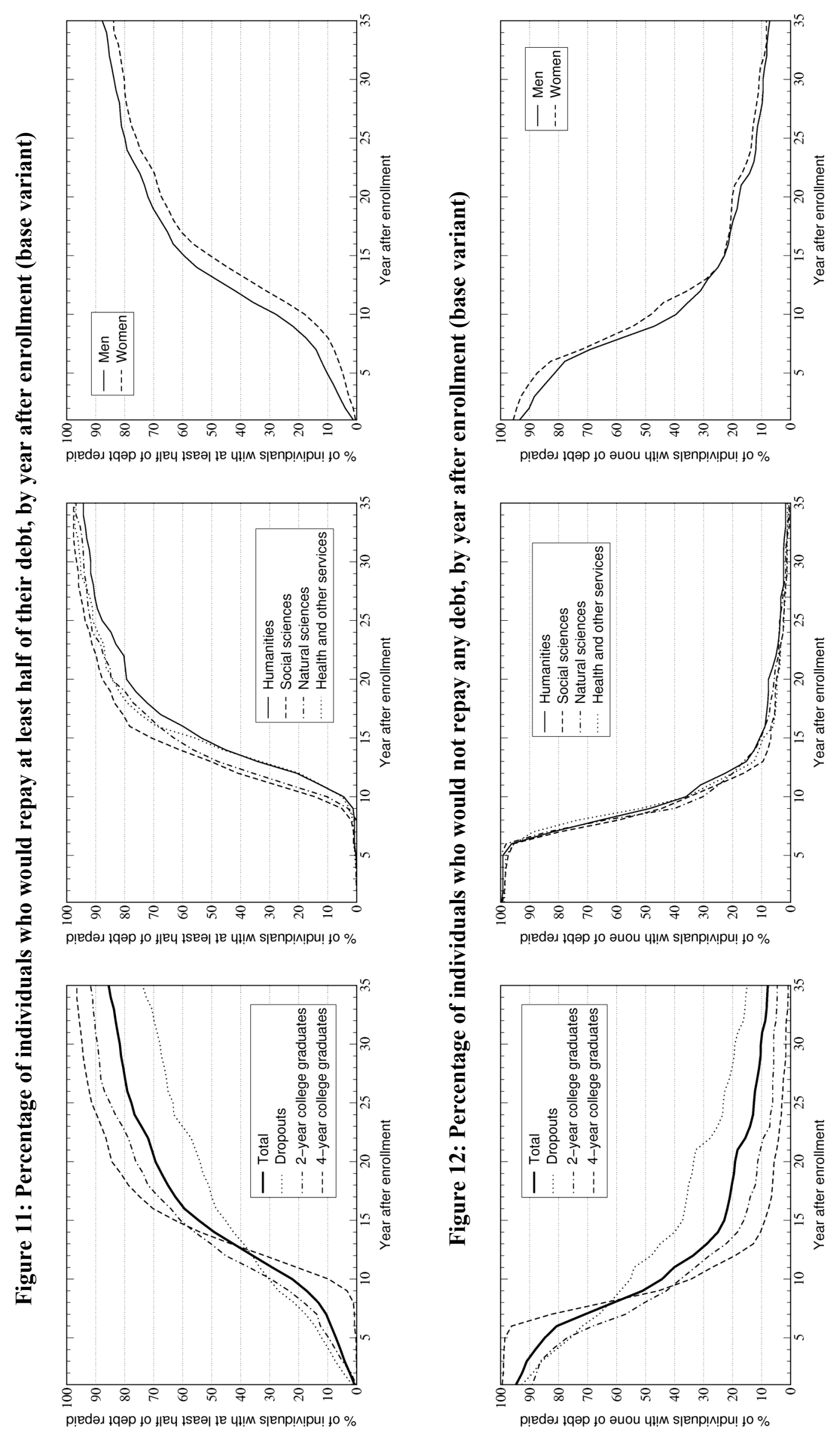


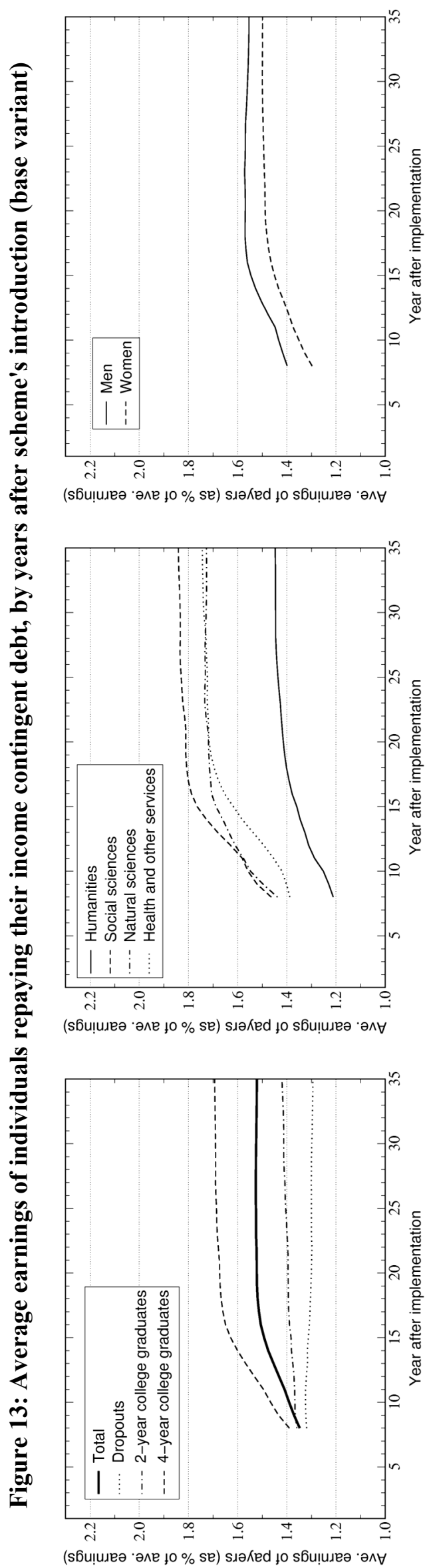



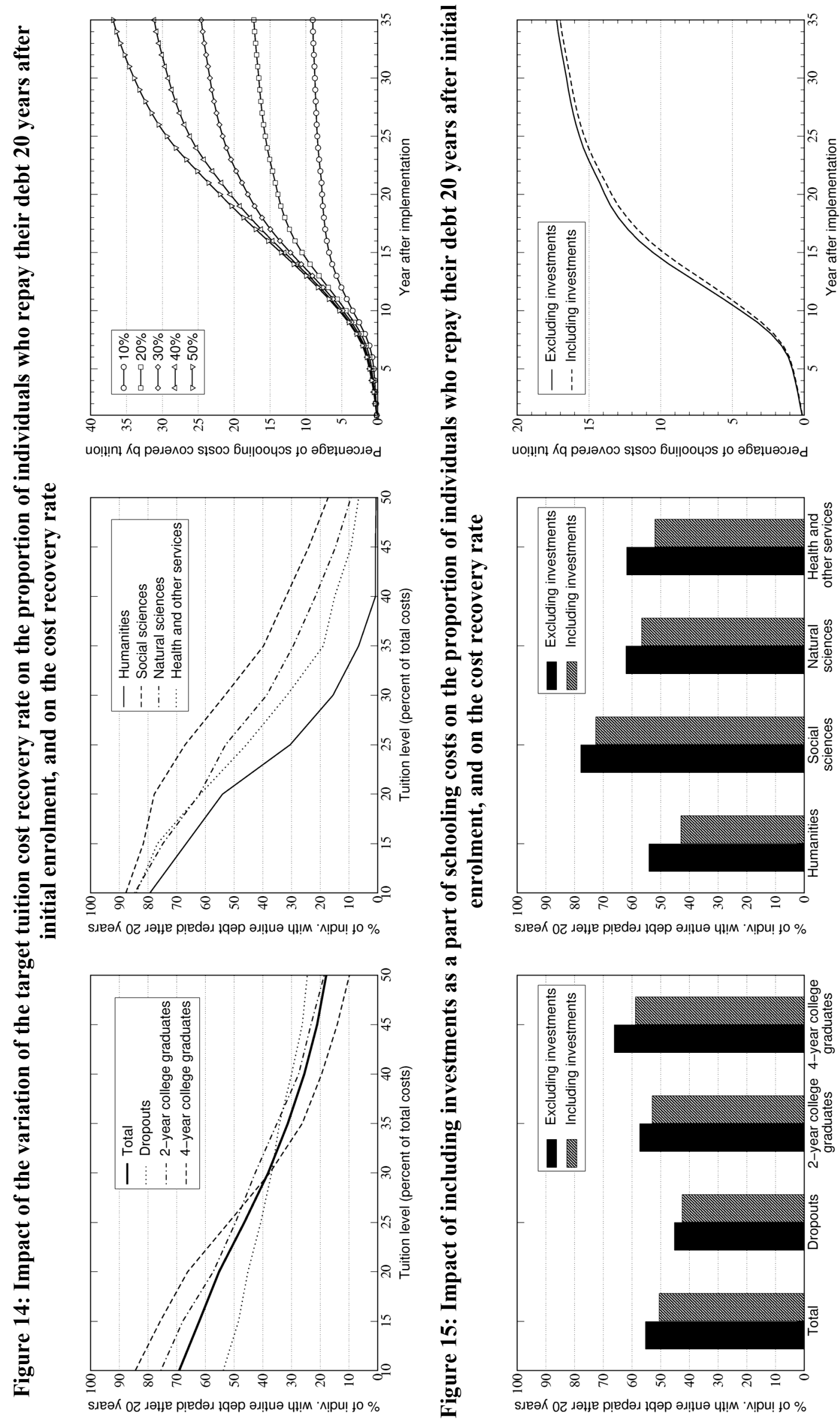

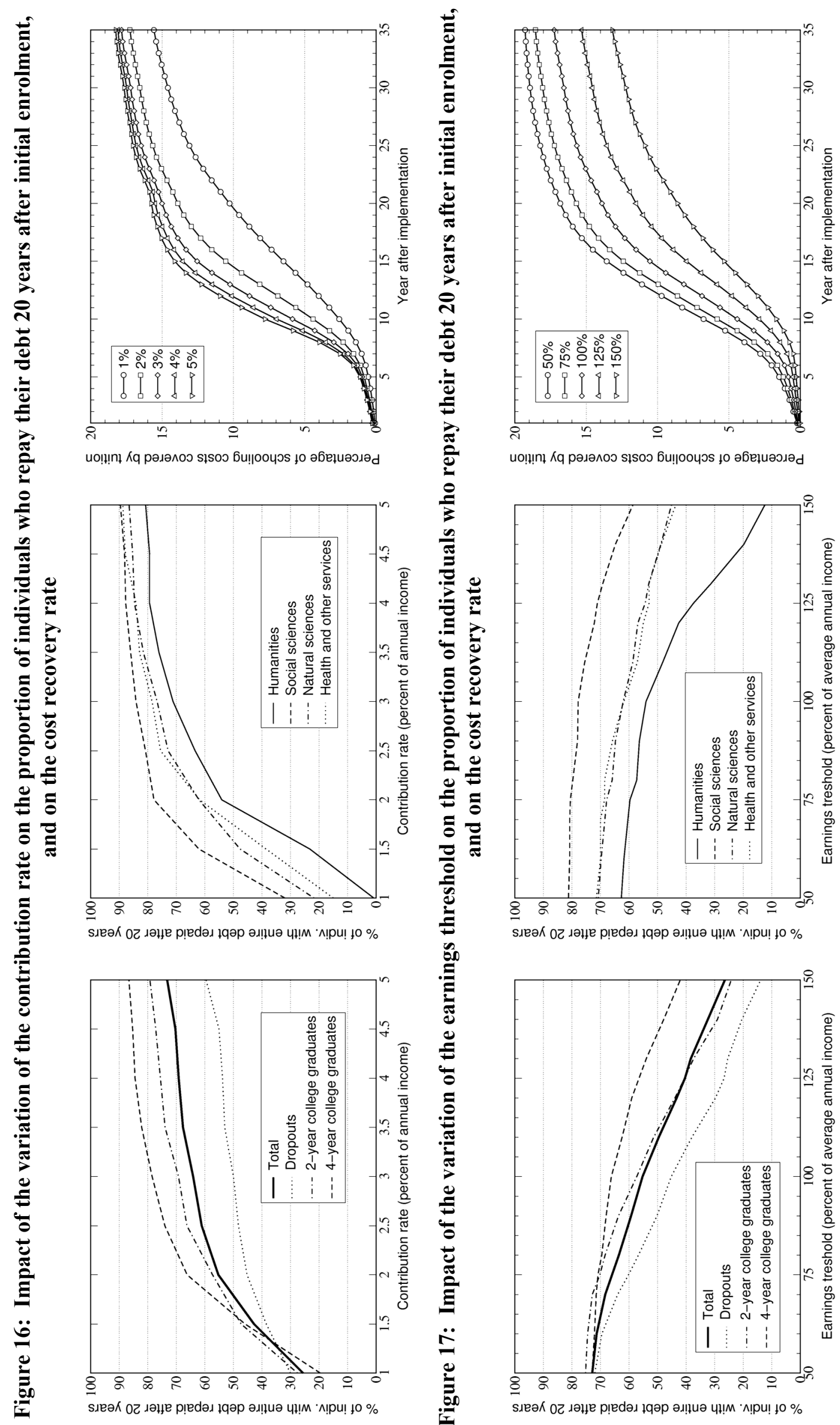

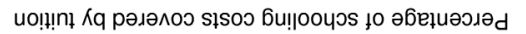

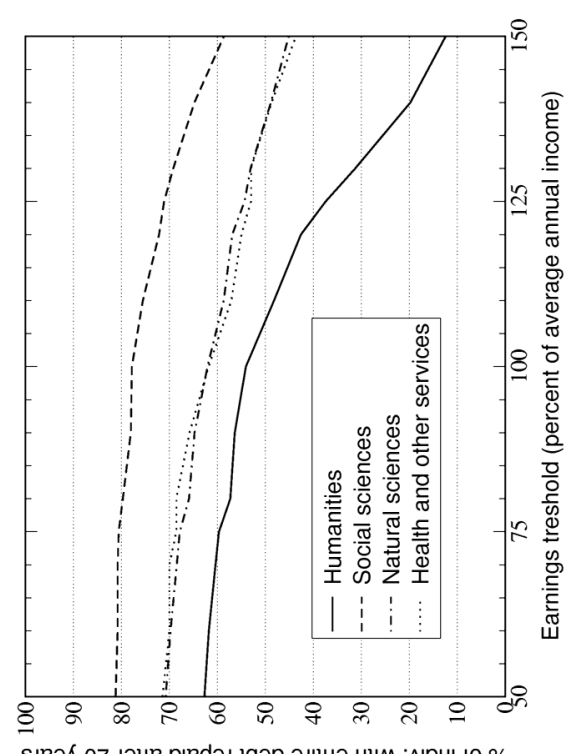



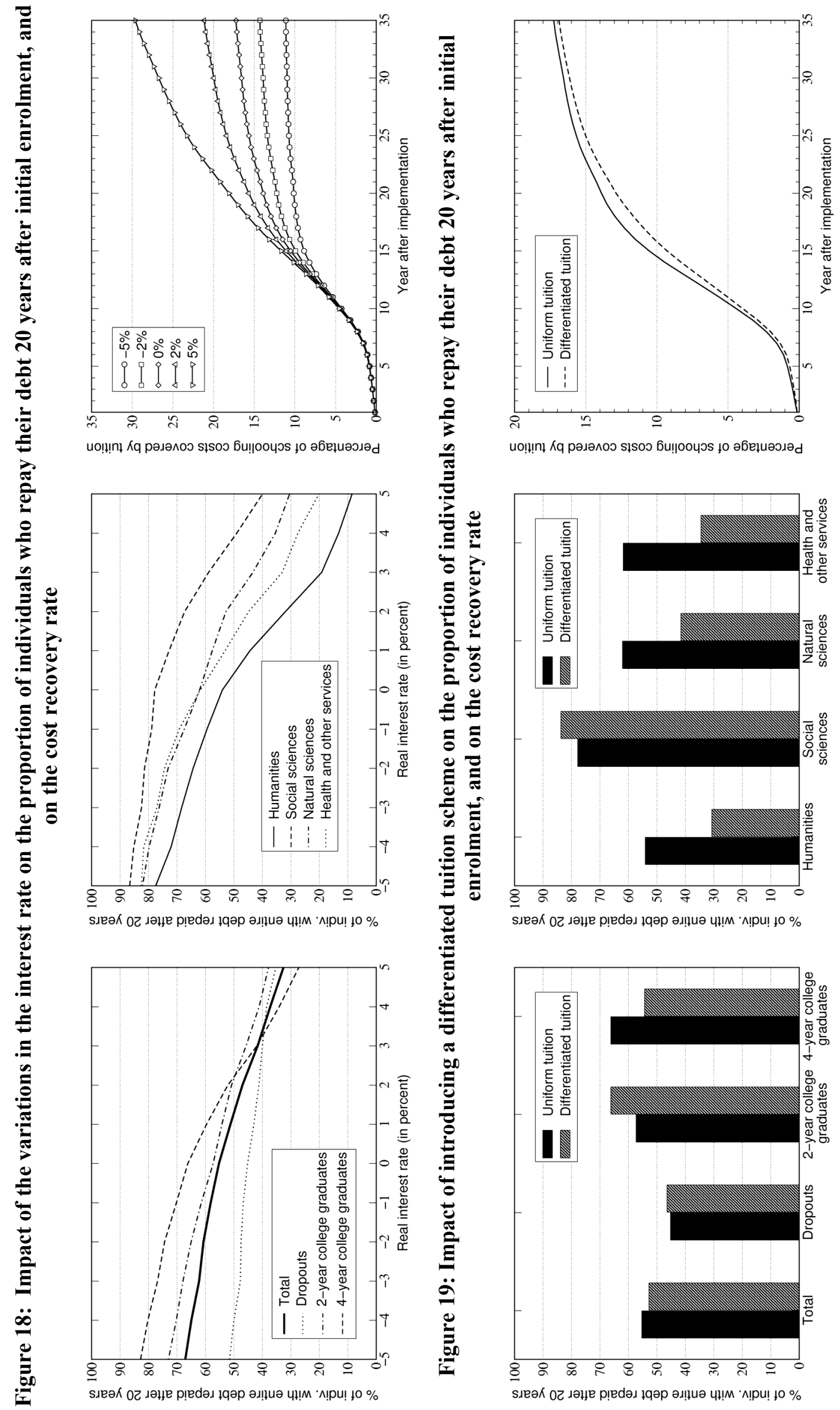

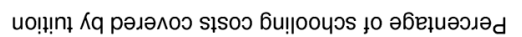

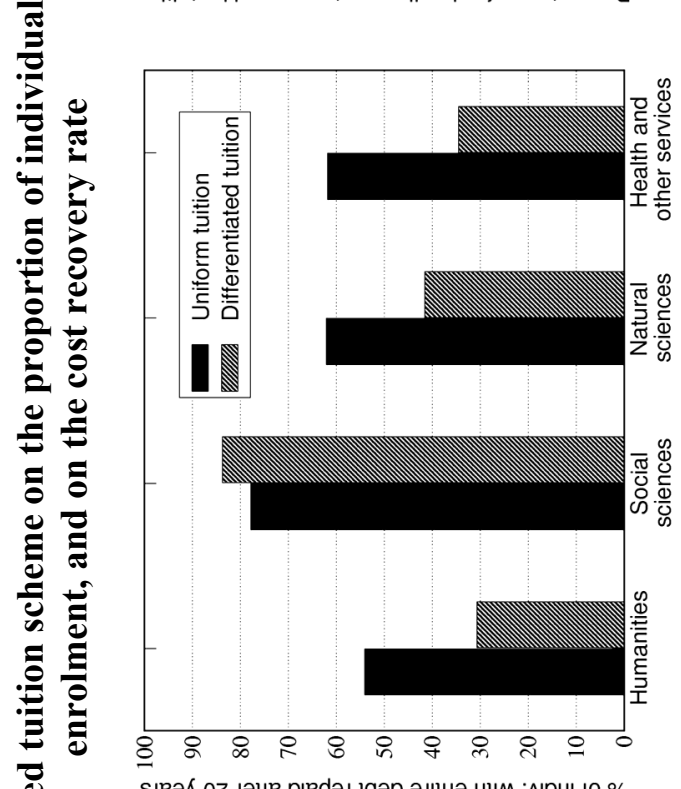

